\title{
Comparison of the milk composition of free-ranging indigenous African cattle breeds
}

\author{
J. Myburgh, G. Osthoff ${ }^{\#}$, A. Hugo, M. de Wit, K. Nel \& D. Fourie \\ Department of Microbial, Biochemical and Food Biotechnology, University of the Free State, Bloemfontein, \\ South Africa
}

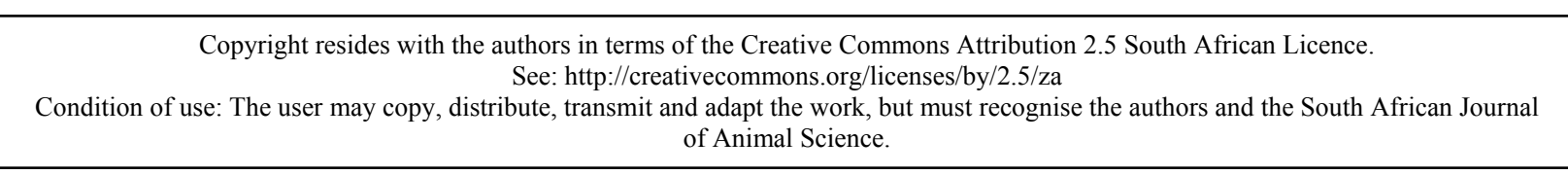

\begin{abstract}
The milk composition of free-ranging indigenous African cattle breeds was analysed. These breeds were chosen because they have not been bred specifically for milk production and might be considered the closest to a "natural" or "wild type" of the Bos species. It was found that the nutrient composition of the milk of these cattle, in particular the dry matter, is as low as that of European beef breeds. The content of whey proteins and NPN is also lower than that of dairy breeds. Statistically significant differences in milk fatty acid composition between the Sanga-type cattle and the Afrikaner and its derivatives were observed for the content of lactose, whey protein and non-protein nitrogen, as well as fatty acid composition regarding medium long chain and long chain fatty acids. A genetic relationship is evident and suggests the preference of certain fatty acid synthesis pathways.
\end{abstract}

Keywords: Boran, Nguni, Tuli, Bonsmara, Drakensberger, Afrikaner, fatty acids, proximate analysis

${ }^{\#}$ Corresponding author: osthoffg@ufs.ac.za

\section{Introduction}

Almost all research on cows' milk has involved the milk of dairy breeds of European and Asian origin. These breeds have been developed to purposely produce high volumes of milk, and even specific nutrients. Very little is known about the milk of cows other than the dairy breeds, such as beef breeds. Even less is known about milk from cattle breeds that have not been interfered with by dedicated breeding to improve milk and beef quality such as indigenous African cattle. Until recently, breeding of traditional African cattle was based mainly on survivability against environmental conditions and diseases, rather than on food improvement.

Indigenous African cattle contain genetic markers of both Bos taurus and Bos indicus, and it is believed that they originate from Hamitic longhorn cattle (Bos taurus) from Arabia, and Zebu cattle (Bos indicus) and humpless shorthorn cattle from Asia (Payne, 1970). Breeds such as the Afrikaner, Boran, Nguni, Sanga and Tuli are true African breeds, while the Bonsmara and Drakensberger were developed from the Afrikaner in South Africa by crossbreeding with European breeds (Meyer, 1984).

The Sanga is the dominant breed, from which most of the southern African breeds have been derived, such as the Nguni and Tuli. The Boran became the dominant breed of eastern Africa. It has been bred as a pure breed for 1300 years. The Tuli is a descendant of the Sanga, and was brought to the regions south of the Zambezi around $700 \mathrm{AD}$. The Nguni was brought by the Nguni tribe to the south-eastern area of Swaziland, Zululand and Mozambique. Not much is known about the origins of the Afrikaner. It is said to have crossed into Africa from Aden approximately 2000 years ago and was brought to southern Africa by the Khoi people earlier than the Nguni (Bonsma et al., 1951). It is genetically related to the Sanga types (Meyer, 1984). Although these cattle have been used traditionally to obtain milk, they are not used for commercial milk production, but instead, in some areas, for meat production (Strydom, 2008). It was shown by Meyer (1984) that the genetic differences may be followed by genetic markers for the milk proteins, $\beta$-casein and $\alpha$-lactalbumin, and also the blood proteins, haemoglobin and albumin. 
European settlers brought new agricultural practices and imported the less adapted Bos taurus breeds for their perceived higher income, coupled with better carcass quality. These were crossbred with indigenous breeds to develop inter alia the Drakensberger and Bonsmara. Crossbreeding of the Afrikaner with some European breeds resulted in the Drakensberger, while the Bonsmara composition was created by approximately 5/8 Afrikaner, 3/16 Shorthorn and 3/16 Hereford (Bonsma et al., 1951; Bonsma, 1980). These three cattle breeds are also employed as beef breeds (Strydom, 2008).

Since the African indigenous cattle had been least affected by dedicated breeding for food quality until approximately 50 years ago, they might be regarded as being the closest to a "natural" Bos species to represent the Bovidae family in a comparative study of milk composition across all mammalian species. No detailed data on the milk of these breeds are available.

Research on energy provision by milk energy components has received great interest (Oftedal, 1984; Tilden \& Oftedal, 1997; Power et al., 2002), as has the fatty acid content of and deposition in milk fat (Dils et al., 1977; Iverson \& Oftedal, 1995; Milligan et al., 2008). This aspect is important, because certain long chain unsaturated fatty acids have been shown to play a direct role in the neuro-development of infants (Makrides et al., 1994; Kothapalli et al., 2007). The fatty acid composition in milk differs between species. In species with foregut fermentation, in particular the ruminants, the ingested fatty acids are changed by fermentation, mainly hydrogenated. Every species of monogastric digesters, such as the lion (De Waal et al., 2005), cat (Jacobsen, 2004), pig (Csapó et al., 1996) and primates (Milligan et al., 2008; Osthoff et al., 2009a), and hindgut fermenters, such as the African elephant (Osthoff et al., 2005), seems to have a unique need for certain fatty acids and the milk fat composition may be dictated by a preference for the incorporation of dietary fatty acids or de novo synthesized medium chain (8:0 - 14:0) fatty acids.

In ruminants, de novo synthesis of medium chain fatty acids is performed from lactate, acetate, and 3-hydroxybutyrate, which are metabolites from the fermentation of carbohydrates by the rumen bacteria, as substrates. The length of de novo synthesized fatty acids depends on the particular properties of enzymes in the synthesis pathway. Fatty acids are synthesized by fatty acid synthase in an elongation process. In the liver and adipose tissue, the fatty acids attain a chain length of 16 carbons or more. In the mammary gland, the synthesis is terminated by a thioesterase before a chain length of 16 carbons is reached. Depending on the properties of the thioesterase, this termination may be effected after elongation of 8 to 14 carbons (Neville et al., 1983).

Among the non-ruminants, such as bats (Hood et al., 2001) and primates (Milligan et al., 2008; Osthoff et al., 2009a), there is evidence that ecological (diet) factors, as well as phylogenic (genetic) factors, may contribute to differences in fatty acid composition of milk fat. To date, such observations among ruminants are still unclear, although it is known that members of at least the Caprinae sub-family, specifically the sheep (Ovis aries) (Haenlein \& Wendorff, 2006) and goat (Capra hircus) (Park, 2006), may contain 10\% - 19\% medium chain (8:0-12:0) fatty acids in milk fat (Talpur et al., 2009) compared with less than $10 \%$ in other ruminant milk. A single sample of okapi milk that was analysed may suggest that concentrations higher than $10 \%$ are also found in milk of the Giraffidae (Glass \& Jenness, 1971). Among the Bovini tribe of the Bovinae subfamily, the proximate and fatty acid composition of the domesticated cow (Jenness \& Patton, 1976), yak (Lkhagvajav, 1978), water buffalo (Bubalus bubalis) (Jensen, 1995) and African buffalo (Syncerus caffer) (Osthoff et al., 2009b) differ. Regarding the fatty acids, the greatest differences were shown to occur in 16:0, 18:0 and 18:1 (Pandya \& Khan, 2006; Osthoff et al., 2009b).

Medium chain length fatty acids are formed owing to the termination of elongation after 8 to 14 carbons by a thioesterase (Neville et al., 1983). Little emphasis is placed on the composition of myristic acid (14:0) in the comparisons of milk among species. The reason might be that the greatest differences in medium chain fatty acid composition in milks are observed in the 8:0 to 12:0 acids (Iverson \& Oftedal, 1995). The 14:0 content is very constant at below $10 \%$. Levels above $10 \%$ have been detected in only a few species, such as the brown lemur (Eulemur fulvus), slow loris (Nycticebus coucang) (Myher et al., 1994) and Norway rat (Rattus norwegicus) (Mills et al., 1990). In general, only ruminant milks contain above $10 \%$ of 14:0, but contents above $18 \%$ have been found only in the blesbok and blue wildebeest of the Elaphinae subfamily (Osthoff et al., 2009c).

The fatty acid composition of ruminant milk is linked to intrinsic factors (animal species, breed, genotype, pregnancy and lactation stages) or extrinsic (environmental). In a given animal species, the effects linked to breed or genotype are significant, but restricted, and they can be achieved only over the long term. Nevertheless, the efficiency of transfer of long chain poly-unsaturated fatty acids to milk is low owing to 
extensive biohydrogenation by the rumen bacteria (Jenkins, 1993; French et al., 2000; Chilliard et al., 2001). In agricultural practices, this may be achieved by chemical protection of the fatty acids with polysaccharides for post-rumen release (Offer et al., 1999; Jenkins \& Bridges, 2007).

The composition of cows' milk from dairy breeds is well known. Since these breeds have been altered intensively by dedicated breeding for food quality, they are not suitable representatives for interspecies comparison of milks. African indigenous cattle have been least affected by dedicated breeding, and might be considered the closest to a "natural" or "wild type" of Bos species as representative of the Bovidae family in a comparative study of milk composition. No detailed data on the milk of these breeds are available. Such data would be useful for nutritional knowledge of mammals in general and calf rearing in particular. To imitate natural conditions, free-roaming animals should be used for such an investigation. To counter the effect of nutrition and other environmental factors on milk composition, the study area should be small and contain the same vegetation. We report the milk composition of four African cattle breeds, the Afrikaner, Boran, Nguni, Tuli, and two composite breeds, the Bonsmara and Drakensberger.

\section{Material and Methods}

Milk samples were collected from non-dairy cattle breeds within a $50 \mathrm{~km}$ radius of Bloemfontein, South Africa. The animals were free ranging, and no form of nutrient supplement was provided. The vegetation type of the area is known as Dry Cymbopogon-Themeda veld (Acocks, 1988). Two herds each of Afrikaner, Bonsmara, Boran and Drakensberger and three herds each of Nguni and Tuli were sampled, and all the cows were in the peak stage of lactation. The peak stage, between weeks 7 and 10 (Jenkins \& Ferrell, 1984), was selected, because the least changes in nutrients occur during this stage. Thus, the exact postpartum date of collection was not so important. Three cows of each herd were hand-milked and milk of all four quarters was pooled, mixed and subdivided for storage in $50 \mathrm{~mL}$ sterile bottles. No milk-letting agent was administered. Milk was kept on ice while in the field for $1-2 \mathrm{~h}$ until freezing facilities were available. The milk samples were then subdivided into $100 \mu \mathrm{L}$ in Eppendorf tubes and stored at $-20{ }^{\circ} \mathrm{C}$ until all the samples had been collected, which took two weeks. For analysis, milk was thawed and mixed by swirling at $39^{\circ} \mathrm{C}$ in a water bath.

Crude protein content was determined with a Leco ${ }^{\circledR}$ nitrogen $(\mathrm{N})$ analyser (Leco Corporation, 2001) and then the total nitrogen content was multiplied by a factor of 6.38. Electrophoresis and identification of protein bands were carried out on a Mighty Small miniature slab gel electrophoresis unit SE 260 (Hoefer Scientific Instruments). Milk samples were diluted 1 : 10 with stacking gel buffer containing 2\% - 5\% sucrose and a trace of bromophenol blue tracking dye. Sample volumes of $5 \mu \mathrm{L}$ milk were applied to the wells of the slab gel.

Non-protein nitrogen (NPN) and whey proteins were fractionated by selective precipitation according to Igarashi's (1995) method, and the protein content of each fraction was determined as above. The fractions were subjected to electrophoresis to enable identification of protein bands on the electrophoretograms.

Extraction of total fat from the milk was performed quantitatively according to Folch et al. (1957), using chloroform and methanol in a ratio of $2: 1$. Total extractable fat concentration was determined by weighing and expressed as $\%$ fat $(\mathrm{w} / \mathrm{w})$ per $100 \mathrm{~g}$ milk. The fat-free dry matter (FFDM) content was determined by weighing the residue on pre-weighed filter paper, used for Folch extraction, after drying. By determining the difference in weight, the FFDM could be expressed as \% FFDM (w/w) per $100 \mathrm{~g}$ milk. The moisture content of the milk was determined by subtraction (100\% - \% lipid - \% FFDM) and expressed as \% moisture (w/w) per $100 \mathrm{~g}$ milk.

Fatty acids were transesterified to form methyl esters using $0.5 \mathrm{~N} \mathrm{NaOH}$ in methanol and $14 \%$ boron trifluoride in methanol (Park \& Goins, 1994). Fatty acid methylesters (FAME) were quantified using a Varian GX 3400 GC, with a flame ionization detector and a fused silica capillary column, Chrompack CPSIL 88 (100 m length, $0.25 \mathrm{~mm}$ ID, $0.2 \mu \mathrm{m}$ film thickness). The column temperature was $40-230{ }^{\circ} \mathrm{C}$ (hold 2 $\mathrm{min} ;{ }^{\circ} \mathrm{C} / \mathrm{min}$; hold $\left.10 \mathrm{~min}\right)$. The solution of FAME in hexane $(1 \mu \mathrm{L})$ was injected into the column using a Varian $8200 \mathrm{CX}$ Autosampler with a split ratio of $100: 1$. The injection port and detector were both maintained at $250{ }^{\circ} \mathrm{C}$. Hydrogen was used as the carrier gas at 45 psi and nitrogen as the makeup gas. Chromatograms were recorded with Varian Star Chromatography Software. Identification of sample FAME was made by comparing the relative retention times of FAME peaks from samples with those of standards obtained from Supelco (Supelco 37 Component FAME Mix 47885-U). Conjugated linoleic acid (CLA) 
standards were obtained from Matreya Inc. Fatty acid concentrations were expressed as the proportion of each individual fatty acid to the total of all fatty acids present in the sample.

Carbohydrates were determined with a Waters Breeze High Performance Liquid Chromatography system using Biorad Aminex 42C (300 x 7.8) mm and Waters Sugar Pak $1(300 \times 7.8) \mathrm{mm}$ columns at $84{ }^{\circ} \mathrm{C}$ with a differential refractive detector. The mobile phase was de-ionized water and eluted at $0.6 \mathrm{~mL} / \mathrm{min}$. Samples were de-fatted and de-proteinized by centrifugation at $3000 \mathrm{~g}$ in Ultrafree-CL (UFC4 LCC 25) filter devices (Millipore), and $10 \mu \mathrm{L}$ of each sample was subsequently injected into the system. Quantification was done with maltotriose, lactose, glucose, galactose and fucose as standards.

Significant differences in means among breeds were determined using analysis of variance (ANOVA) and multiple comparisons between breeds using the Tukey-Kramer test at $\alpha=0.05$ (NCSS, 2007). Statistically significant variables were visualized in a two-dimensional space by principal component analysis (PCA) (NCSS, 2007).

\section{Results and Discussion}

The cattle under study were kept for meat production, were free ranging and were not accustomed to being handled by humans. Not all the cows and calves of the same lactating stage in a herd could be rounded up simultaneously. Difficulties in obtaining milk were encountered with most Afrikaner cows and only a few from the other breeds. Handling and attempted milking caused stress, mainly with the Afrikaner cows, which resulted in failed milk letting, or milk letting that stopped halfway through the collection procedure. Consequently, milk from all four quarters that was suitable for the intended investigation was not obtained from all cows of a herd. It may be argued that the milk composition might have been affected by the stress. However, reported data show that only long-term stress conditions, such as daily abusive handling (De Passillé \& Rushen, 1999) and heat (Kadzere et al., 2002), seem to alter milk composition. These reports show that a simultaneous drop in fat and protein content was observed in the milk of cow and rat (Purcell et al., 2011). Since this does not seem to be the case with the Afrikaner milk samples, it may be assumed that short-term stress did not affect the milk composition.

The proximate analysis of the milk of the six cattle breeds is shown in Table 1 and the fatty acid composition of the fat fraction in Table 2. The milk composition of a dairy breed from the literature is presented as reference (Jenness \& Patton, 1976; Atwal et al., 1990). In general, the dry matter of the milks under study, at approximately $10 \%$, is almost $2 \%$ lower than that found in most dairy breeds, while the lactose content of between $5.16 \pm 0.89 \%$ and $6.74 \pm 0.35 \%$ is higher (Jenness \& Patton, 1976; Atwal et al., 1990). This is in agreement with the data of Litwinczuk \& Krol (2002) from a comparative study between milk from the Hereford, Limousine and Simmental with Holstein milk. The lactose content of the Nguni and Tuli was above $6.2 \%$ and is significantly higher than that of the other breeds, which is less than $5.8 \%$. The fat content of the African breeds is in the same order of magnitude, and comparable with that of dairy cows (Jenness \& Patton 1976; Atwal et al., 1990), as well as the beef breeds reported by Litwinczuk \& Krol (2002). While the milk fat content of the Nguni was the highest at $4.18 \pm 1.64 \%$, it differs significantly only from that of the Tuli, at $2.01 \pm 0.82 \%$, which was the lowest. No significant difference in protein and casein content of the milk was noted between the six breeds. However, the whey content of the Nguni $(0.40 \pm$ $0.23 \%)$ and Tuli $(0.31 \pm 0.33 \%)$ was the lowest and significantly lower than that of the Bonsmara $(1.01 \pm$ $0.47 \%$ ), which was the highest. The casein : whey ratio of the Nguni was $6.3: 1$ and that of the Tuli was $8.7: 1$. The NPN of the Boran, Nguni and Tuli, approximately $0.1 \%$, was significantly lower than that of the Bonsmara and Drakensberger, which was between $0.58 \%$ and $0.63 \%$.

Electrophoresis of the milk proteins resulted in no obvious differences between most milk samples. Two protein bands of $\alpha$-lactalbumin were observed in milk from two Bonsmara cows and one Drakensberger cow (Figure 1). This might be an indication of the occurrence of isomers of this protein, with the upper band representing $\alpha$-lactalbumin type A, typical of the Sanga types, while the second band may be $\alpha$-lactalbumin type B, which is inherited from the European Bos taurus line (Meyer, 1984). No isomers of $\beta$-casein were noted (Meyer, 1984).

The fatty acid composition of the milks is given in Table 2. Since dairy cattle are fed supplementary feed, which is known to affect the fatty acid composition (Atwal et al., 1990; Chilliard et al., 2001; Chilliard et al., 2007), a detailed quantitative comparison with the literature was not attempted. 
Table 1 Proximate analysis $(\mathrm{g} / 100 \mathrm{~g}$ milk $\pm \mathrm{SD})$ of milk from African cattle breeds, the Boran, Nguni, Tuli, Afrikaner, Bonsmara and Drakensberger with a dairy cow's milk as reference

\begin{tabular}{|c|c|c|c|c|c|c|c|c|}
\hline Proximate analysis & ${ }^{1}$ Dairy cow & $\begin{array}{l}\text { Boran } \\
n=6\end{array}$ & $\begin{array}{l}\text { Nguni } \\
\mathrm{n}=9\end{array}$ & $\begin{array}{c}\text { Tuli } \\
\mathrm{n}=10\end{array}$ & $\begin{array}{c}\text { Afrikaner } \\
n=6\end{array}$ & $\begin{array}{c}\text { Bonsmara } \\
n=6\end{array}$ & $\begin{array}{c}\text { Drakensberger } \\
\qquad n=6\end{array}$ & $\begin{array}{c}\text { Significance } \\
\text { level }\end{array}$ \\
\hline Fat $(\%)$ & 3.9 & $2.68^{\mathrm{ab}} \pm 0.98$ & $4.18^{b} \pm 1.64$ & $2.01^{\mathrm{a}} \pm 0.82$ & $3.79^{\mathrm{ab}} \pm 1.30$ & $3.76^{\mathrm{ab}} \pm 1.23$ & $3.63^{\mathrm{ab}} \pm 0.49$ & $P<0.05$ \\
\hline Fat-free dry matter $(\%)$ & & $5.66 \pm 0.90$ & $6.48 \pm 1.20$ & $6.72 \pm 1.29$ & $5.15 \pm 1.20$ & $5.75 \pm 1.31$ & $5.51 \pm 1.20$ & NS \\
\hline Moisture (\%) & 87.1 & $91.7 \pm 2.65$ & $89.3 \pm 1.26$ & $91.3 \pm 1.56$ & $91.1 \pm 1.20$ & $90.5 \pm 1.33$ & $90.9 \pm 1.03$ & NS \\
\hline Lactose (\%) & 4.8 & $5.16^{\mathrm{a}} \pm 0.89$ & $6.59^{b} \pm 0.30$ & $6.74^{b} \pm 0.35$ & $5.64^{\mathrm{a}} \pm 0.14$ & $5.47^{\mathrm{a}} \pm 0.16$ & $5.43^{\mathrm{a}} \pm 0.50$ & $P<0.001$ \\
\hline Total N protein $(\%)$ & 3.3 & $3.61 \pm 0.43$ & $2.96 \pm 0.82$ & $3.02 \pm 0.33$ & $3.16 \pm 0.42$ & $3.20 \pm 0.40$ & $3.26 \pm 0.52$ & NS \\
\hline Casein $(\%)$ & 2.6 & $3.00 \pm 0.41$ & $2.55 \pm 0.77$ & $2.71 \pm 0.44$ & $2.45 \pm 0.37$ & $2.19 \pm 0.63$ & $2.73 \pm 0.49$ & NS \\
\hline Whey (\%) & 0.6 & $0.61^{\mathrm{ab}} \pm 0.34$ & $0.40^{\mathrm{a}} \pm 0.23$ & $0.31^{\mathrm{a}} \pm 0.33$ & $0.70^{\mathrm{ab}} \pm 0.42$ & $1.01^{\mathrm{b}} \pm 0.47$ & $0.52^{\mathrm{ab}} \pm 0.28$ & $P<0.01$ \\
\hline NPN (\%) & & $0.10^{\mathrm{a}} \pm 0.03$ & $0.09^{\mathrm{a}} \pm 0.01$ & $0.11^{\mathrm{a}} \pm 0.03$ & $0.31^{\mathrm{ab}} \pm 0.26$ & $0.58^{\mathrm{b}} \pm 0.39$ & $0.63^{\mathrm{b}} \pm 0.25$ & $P<0.001$ \\
\hline
\end{tabular}

$\mathrm{SD}$ - standard deviation; NS - not significant; NPN - non-protein nitrogen.

For each breed (Boran, Nguni, Tuli, Bonsmara, Drakensberger, Afrikaner), mean values in the same row with different superscripts (a, b) presented significant differences.

${ }^{1}$ Jennes \& Patton (1976). 
Table 2a Saturated fatty acid content (\% of total fatty acids \pm SD) of the milk fat of indigenous African cattle breeds, with dairy cow milk as reference

\begin{tabular}{|c|c|c|c|c|c|c|c|c|c|}
\hline \multicolumn{2}{|c|}{ FAME ( $\%$ of total fatty acids) } & ${ }^{1}$ Dairy cow & $\begin{array}{c}\text { Boran } \\
\mathrm{n}=6\end{array}$ & $\begin{array}{c}\text { Nguni } \\
\mathrm{n}=9\end{array}$ & $\begin{array}{c}\text { Tuli } \\
\mathrm{n}=10\end{array}$ & $\begin{array}{c}\text { Afrikaner } \\
\mathrm{n}=6\end{array}$ & $\begin{array}{c}\text { Bonsmara } \\
n=6\end{array}$ & $\begin{array}{c}\text { Drakensberger } \\
\qquad n=6\end{array}$ & $\begin{array}{c}\text { Significance } \\
\text { level }\end{array}$ \\
\hline Butyric & $\mathrm{C} 4: 0$ & 3.2 & $0.70^{\mathrm{ab}} \pm 0.16$ & $0.49^{\mathrm{a}} \pm 0.32$ & $0.41^{\mathrm{a}} \pm 0.34$ & $0.97^{\mathrm{b}} \pm 0.10$ & $0.96^{\mathrm{b}} \pm 0.09$ & $0.95^{\mathrm{b}} \pm 0.13$ & $P<0.001$ \\
\hline Caproic & C6:0 & 1.7 & $0.99^{\mathrm{ab}} \pm 0.22$ & $0.75^{\mathrm{a}} \pm 0.39$ & $0.73^{\mathrm{a}} \pm 0.35$ & $1.23^{\mathrm{b}} \pm 0.19$ & $1.33^{\mathrm{b}} \pm 0.15$ & $1.41^{\mathrm{b}} \pm 0.27$ & $P<0.001$ \\
\hline Caprylic & $\mathrm{C} 8: 0$ & 1.3 & $0.71^{\mathrm{ab}} \pm 0.20$ & $0.62^{\mathrm{a}} \pm 0.29$ & $0.67^{\mathrm{a}} \pm 0.12$ & $1.00^{\mathrm{bc}} \pm 0.17$ & $1.07^{\mathrm{bc}} \pm 0.15$ & $1.28^{\mathrm{c}} \pm 0.20$ & $P<0.001$ \\
\hline Capric & $\mathrm{C} 10: 0$ & 3.4 & $1.68^{\mathrm{ab}} \pm 0.62$ & $1.62^{\mathrm{ab}} \pm 0.52$ & $1.56^{\mathrm{a}} \pm 0.33$ & $2.41^{b c} \pm 0.44$ & $2.79^{\mathrm{cd}} \pm 0.68$ & $3.43^{\mathrm{d}} \pm 0.57$ & $P<0.001$ \\
\hline Hendecanoic & $\mathrm{C} 11: 0$ & & ND & ND & ND & ND & ND & ND & NSA \\
\hline Lauric & $\mathrm{C} 12: 0$ & 4.2 & $2.26^{\mathrm{ab}} \pm 0.73$ & $2.11^{\mathrm{a}} \pm 0.63$ & $2.06^{\mathrm{a}} \pm 0.41$ & $3.04^{\mathrm{bc}} \pm 0.43$ & $3.55^{\mathrm{cd}} \pm 0.75$ & $4.33^{\mathrm{d}} \pm 0.53$ & $P<0.001$ \\
\hline Tridecoic & C13:0 & & ND & ND & $0.01 \pm 0.03$ & ND & ND & ND & NSA \\
\hline Myristic & $\mathrm{C} 14: 0$ & 13.8 & $10.01^{\mathrm{ac}} \pm 1.08$ & $9.43^{\mathrm{ab}} \pm 2.15$ & $8.60^{\mathrm{a}} \pm 1.09$ & $11.50^{\mathrm{bc}} \pm 1.34$ & $12.72^{\text {cd }} \pm 1.68$ & $14.50^{\mathrm{d}} \pm 0.97$ & $P<0.001$ \\
\hline Pentadecylic & $\mathrm{C} 15: 0$ & & $1.24 \pm 0.44$ & $1.29 \pm 0.32$ & $1.44 \pm 0.23$ & $1.48 \pm 0.31$ & $1.46 \pm 0.22$ & $1.46 \pm 0.09$ & NS \\
\hline Palmitic & $\mathrm{C} 16: 0$ & 32.2 & $31.23^{\mathrm{ab}} \pm 2.20$ & $33.27^{\mathrm{ab}} \pm 6.58$ & $32.11^{\mathrm{a}} \pm 2.04$ & $36.89^{\mathrm{ab}} \pm 3.84$ & $35.78^{\mathrm{ab}} \pm 4.19$ & $38.73^{b} \pm 3.28$ & $P<0.05$ \\
\hline Margaric & C17:0 & 0.6 & $0.90 \pm 0.34$ & $0.98 \pm 0.38$ & $1.31 \pm 0.48$ & $1.22 \pm 0.24$ & $1.01 \pm 0.11$ & $1.13 \pm 0.26$ & NS \\
\hline Stearic acid & C18:0 & 12.6 & $13.43 \pm 3.99$ & $12.22 \pm 2.98$ & $10.91 \pm 1.26$ & $10.90 \pm 2.11$ & $11.48 \pm 1.79$ & $10.26 \pm 0.61$ & NS \\
\hline Nonoadecanoic & C19:0 & & $0.23^{\mathrm{ab}} \pm 0.07$ & $0.21^{\mathrm{a}} \pm 0.11$ & $0.27^{\mathrm{ab}} \pm 0.13$ & $0.40^{\mathrm{b}} \pm 0.07$ & $0.19^{\mathrm{a}} \pm 0.05$ & $0.23^{\mathrm{ab}} \pm 0.13$ & $P<0.05$ \\
\hline Arachidic & $\mathrm{C} 20: 0$ & 0.2 & $0.39 \pm 0.25$ & $0.46 \pm 0.25$ & $0.45 \pm 0.21$ & $0.64 \pm 0.25$ & $0.42 \pm 0.32$ & $0.64 \pm 0.12$ & NS \\
\hline Heneicosanoic & $\mathrm{C} 21: 0$ & & $0.04 \pm 0.09$ & $0.07 \pm 0.08$ & $0.09 \pm 0.10$ & ND & ND & ND & NS \\
\hline Behenic & $\mathrm{C} 22: 0$ & 0.1 & $0.12 \pm 0.17$ & $0.17 \pm 0.11$ & $0.19 \pm 0.13$ & $0.17 \pm 0.11$ & $0.06 \pm 0.07$ & $0.05 \pm 0.06$ & NS \\
\hline Tricosanoic & $\mathrm{C} 23: 0$ & & $0.07 \pm 0.09$ & $0.01 \pm 0.04$ & $0.07 \pm 0.10$ & $0.02 \pm 0.04$ & ND & ND & NS \\
\hline Lignoceric & $\mathrm{C} 24: 0$ & & ND & $0.02 \pm 0.05$ & ND & ND & ND & ND & NSA \\
\hline
\end{tabular}

FAME - fatty acid methylesters.

SD - standard deviation; NSA - not statistically analysed; NS - not significant; ND - not determined.

For each breed (Boran, Nguni, Tuli, Bonsmara, Drakensberger, Afrikaner) mean values in the same row with different superscripts (a,b) presented significant differences.

${ }^{1}$ Atwal et al., 1990. 
Table $2 \mathbf{b}$ Unsaturated fatty acid content (\% of total fatty acids \pm SD) of the milk fat of indigenous African cattle breeds with dairy cow milk as reference

\begin{tabular}{|c|c|c|c|c|c|c|c|c|c|}
\hline \multicolumn{2}{|c|}{ FAME ( $\%$ of total fatty acids) } & \multirow[t]{2}{*}{${ }^{1}$ Dairy cow } & \multirow{2}{*}{$\begin{array}{c}\text { Boran } \\
\mathrm{n}=6 \\
1.25^{\mathrm{b}} \pm 0.44\end{array}$} & \multirow{2}{*}{$\begin{array}{c}\begin{array}{c}\text { Nguni } \\
\mathrm{n}=9\end{array} \\
.73^{\mathrm{a}} \pm 0.42\end{array}$} & \multirow{2}{*}{$\begin{array}{c}\text { Tuli } \\
\mathrm{n}=10 \\
0.93 \pm 0.18^{\mathrm{ab}}\end{array}$} & \multirow{2}{*}{$\begin{array}{l}\text { Afrikaner } \\
\mathrm{n}=6 \\
0.71^{\mathrm{ab}} \pm 0.24\end{array}$} & \multirow{2}{*}{$\begin{array}{l}\text { Bonsmara } \\
n=6 \\
0.76^{\mathrm{ab}} \pm 0.30\end{array}$} & \multirow{2}{*}{$\begin{array}{c}\text { Drakensberger } \\
\qquad \begin{array}{c}\mathrm{n}=6 \\
0.96^{\mathrm{ab}} \pm 0.16\end{array}\end{array}$} & \multirow{2}{*}{$\begin{array}{c}\begin{array}{c}\text { Significance } \\
\text { level }\end{array} \\
\quad P<0.05\end{array}$} \\
\hline Myristoleic & C14:1c9 & & & & & & & & \\
\hline Pentadecenoic & $\mathrm{C} 15: 1 \mathrm{c} 10$ & 1.1 & ND & ND & ND & ND & ND & ND & NSA \\
\hline Palmitoleic & C16:1c9 & 1.4 & $2.93^{\mathrm{ab}} \pm 0.64$ & $2.40^{\mathrm{ab}} \pm 1.02$ & $3.11^{b} \pm 0.33$ & $2.59^{\mathrm{ab}} \pm 0.28$ & $2.18^{\mathrm{a}} \pm 0.22$ & $2.10^{\mathrm{a}} \pm 0.14$ & $P<0.01$ \\
\hline Heptadecenoic & $\mathrm{C} 17: 1 \mathrm{c} 10$ & & $0.40^{\mathrm{ab}} \pm 0.35$ & $0.43^{\mathrm{ab}} \pm 0.22$ & $0.66^{\mathrm{b}} \pm 0.17$ & $0.33^{\mathrm{a}} \pm 0.16$ & $0.33^{\mathrm{a}} \pm 0.12$ & $0.34^{\mathrm{a}} \pm 0.04$ & $P<0.01$ \\
\hline Elaidic & C18:1t9 & & $1.07 \pm 0.86$ & $1.27 \pm 1.18$ & $0.59 \pm 0.57$ & $1.19 \pm 0.72$ & $0.74 \pm 0.91$ & $1.21 \pm 0.61$ & NS \\
\hline Oleic & C18:1c9 & 20.7 & $26.96^{b c} \pm 2.84$ & $27.77^{c} \pm 7.11$ & $30.39^{c} \pm 4.50$ & $20.27^{\mathrm{ab}} \pm 3.23$ & $20.03^{\mathrm{ab}} \pm 3.44$ & $14.84^{\mathrm{a}} \pm 1.53$ & $P<0.001$ \\
\hline Vaccenic & $\mathrm{C} 18: 1 \mathrm{c} 7$ & & $0.29^{\mathrm{ab}} \pm 0.09$ & $0.26^{\mathrm{ab}} \pm 0.12$ & $0.42^{\mathrm{b}} \pm 0.19$ & $0.29^{\mathrm{ab}} \pm 0.14$ & $0.22^{\mathrm{ab}} \pm 0.07$ & $0.20^{\mathrm{a}} \pm 0.10$ & $P<0.05$ \\
\hline Linolelaidic & C18:2t9,12(n-6) & & $0.07 \pm 0.11$ & $0.12 \pm 0.10$ & $0.07 \pm 0.08$ & $0.04 \pm 0.06$ & $0.08 \pm 0.06$ & $0.07 \pm 0.08$ & $\mathrm{NS}$ \\
\hline Linoleic & C18:2c9,12 (n-6) & 2.8 & $1.74 \pm 0.28$ & $1.40 \pm 0.76$ & $1.37 \pm 0.23$ & $1.46 \pm 0.21$ & $1.30 \pm 0.52$ & $1.16 \pm 0.15$ & NS \\
\hline CLA & C18:2c9t11(n-6) & & $0.42 \pm 0.35$ & $0.59 \pm 0.41$ & $0.45 \pm 0.20$ & $0.43 \pm 0.11$ & $0.68 \pm 0.23$ & $0.23 \pm 0.11$ & NS \\
\hline$\alpha$-Linolenic & $\mathrm{C} 18: 3 \mathrm{c} 9,12,15(\mathrm{n}-3)$ & 0.4 & $0.38^{\mathrm{ab}} \pm 0.14$ & $0.60^{\mathrm{b}} \pm 0.35$ & $0.45^{\mathrm{ab}} \pm 0.19$ & $0.54^{\mathrm{ab}} \pm 0.09$ & $0.76^{\mathrm{b}} \pm 0.11$ & $0.23^{\mathrm{a}} \pm 0.18$ & $P<0.01$ \\
\hline$\gamma$-Linolenic & C18:3c6,9,12 (n-6) & & ND & ND & ND & ND & ND & ND & NSA \\
\hline Eicosenoic & C20:1c11 & & $0.34 \pm 0.42$ & $0.36 \pm 0.17$ & $0.35 \pm 0.15$ & $0.28 \pm 0.09$ & $0.13 \pm 0.17$ & $0.24 \pm 0.13$ & NS \\
\hline Eicosadienoic & C20:2c11,14 (n-6) & & $0.14 \pm 0.19$ & $0.33 \pm 0.17$ & $0.25 \pm 0.13$ & ND & ND & ND & NS \\
\hline Eicosatrienoic & C20:3c11,14,17 (n-3) & & ND & ND & $0.01 \pm 0.03$ & ND & ND & ND & NSA \\
\hline Eicosatrienoic & C20:3c8,11,14 (n-6) & & ND & ND & ND & ND & ND & ND & NSA \\
\hline Arachidonic & $\mathrm{C} 20: 4 \mathrm{c} 5,8,11,14(\mathrm{n}-6)$ & 0.2 & $0.04 \pm 0.08$ & $0.01 \pm 0.04$ & $0.06 \pm 0.08$ & ND & ND & ND & NS \\
\hline Eicosopentaenoic & $\mathrm{C} 20: 5 \mathrm{c} 5,8,11,14,17(\mathrm{n}-3)$ & & ND & ND & ND & ND & ND & ND & NSA \\
\hline Docosapentaenoic & $\mathrm{C} 22: 5 \mathrm{c} 7,10,13,16,19(\mathrm{n}-3)$ & & ND & ND & ND & ND & ND & ND & NSA \\
\hline Docosahexanoic & $\mathrm{C} 22: 6 \mathrm{c} 4,7,10,13,16,19(\mathrm{n}-3)$ & & ND & ND & ND & ND & ND & ND & NSA \\
\hline Erucic & $\mathrm{C} 22: 1 \mathrm{c} 13$ & & ND & ND & $0.01 \pm 0.05$ & ND & ND & ND & NSA \\
\hline Docosadienoic & $C 22: 2 c 13,16(n-6)$ & & ND & ND & ND & ND & ND & ND & NSA \\
\hline Nervonic & $\mathrm{C} 24: 1 \mathrm{c} 15$ & & ND & ND & ND & ND & ND & ND & NSA \\
\hline
\end{tabular}

CLA - Conjugated linoleic acid; SD - standard deviation; NSA - not statistically analyzed; NS - not significant; ND - not determined.

For each breed (Boran, Nguni, Tuli, Bonsmara, Drakensberger, Afrikaner), mean values within the same row with different superscripts (a,b) presented significant differences. ${ }^{1}$ Atwal et al., 1990. 
Table 2c Fatty acid ratios ( $\%$ of total fatty acids \pm SD) of the milk fat of indigenous African cattle breeds with dairy cow milk as reference

\begin{tabular}{|c|c|c|c|c|c|c|c|}
\hline FAME ( $\%$ of total fatty acids) & $\begin{array}{c}\text { Boran } \\
n=6\end{array}$ & $\begin{array}{c}\text { Nguni } \\
\mathrm{n}=9\end{array}$ & $\begin{array}{c}\text { Tuli } \\
\mathrm{n}=10\end{array}$ & $\begin{array}{l}\text { Afrikaner } \\
n=6\end{array}$ & $\begin{array}{c}\text { Bonsmara } \\
n=6\end{array}$ & $\begin{array}{c}\text { Drakensberger } \\
\qquad n=6\end{array}$ & $\begin{array}{c}\text { Significance } \\
\text { level }\end{array}$ \\
\hline Total saturated fatty acids & $64.0^{\mathrm{ac}} \pm 4.33$ & $63.7^{\mathrm{ab}} \pm 8.58$ & $60.9^{\mathrm{a}} \pm 4.72$ & $71.9^{\text {bcd }} \pm 3.72$ & $72.8^{\mathrm{cd}} \pm 4.30$ & $78.4^{\mathrm{d}} \pm 2.32$ & $P<0.001$ \\
\hline Total mono-unsaturated fatty acids & $33.2^{\text {bcd }} \pm 3.81$ & $33.2^{\mathrm{cd}} \pm 7.69$ & $36.5^{\mathrm{d}} \pm 5.06$ & $25.7^{\mathrm{ac}} \pm 3.62$ & $24.4^{\mathrm{ab}} \pm 3.84$ & $19.9^{\mathrm{a}} \pm 2.12$ & $P<0.001$ \\
\hline Total poly-unsaturated fatty acids & $2.79 \pm 0.60$ & $3.06 \pm 1.50$ & $2.65 \pm 0.54$ & $2.46 \pm 0.41$ & $2.82 \pm 0.51$ & $1.68 \pm 0.30$ & NS \\
\hline Total omega-3 fatty acids & $0.38^{\mathrm{ab}} \pm 0.14$ & $0.60^{\mathrm{b}} \pm 0.35$ & $0.45^{\mathrm{ab}} \pm 0.20$ & $0.54^{\mathrm{ab}} \pm 0.09$ & $0.76^{b} \pm 0.11$ & $0.23^{\mathrm{a}} \pm 0.18$ & $P<0.01$ \\
\hline Total omega- 6 fatty acids & $2.41 \pm 0.47$ & $2.46 \pm 1.18$ & $2.20 \pm 0.37$ & $1.92 \pm 0.34$ & $2.05 \pm 0.43$ & $1.45 \pm 0.25$ & NS \\
\hline
\end{tabular}

$\mathrm{SD}=$ Standard deviation

NS $=$ Not significant.

For each breed (Boran, Nguni, Tuli, Bonsmara, Drakensberger, Afrikaner), mean values within the same row with different superscripts (a,b,c,d) presented significant differences. 


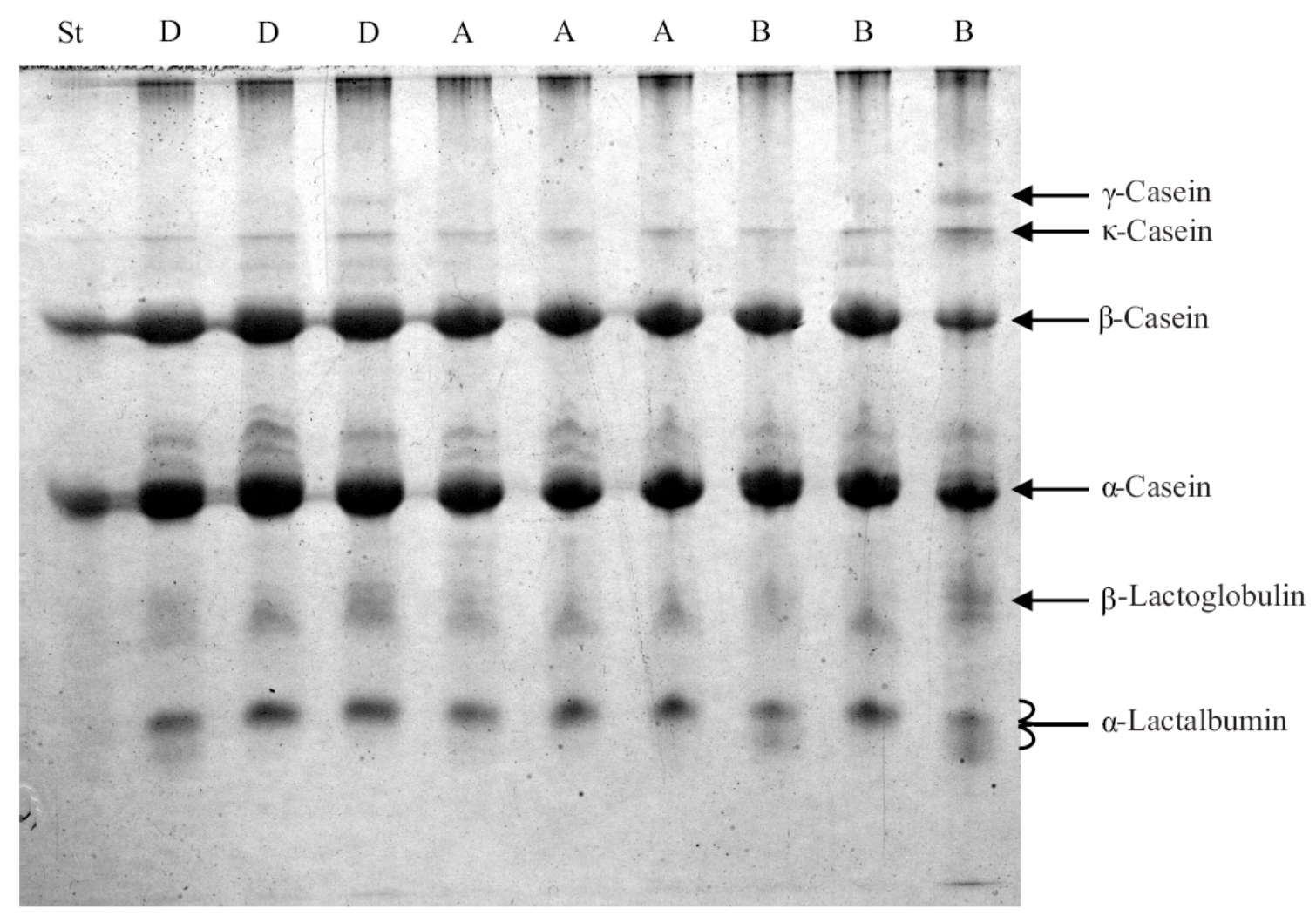

Figure 1 Electrophoretogram of milk from Afrikaner (A), Bonsmara (B) and Drakensberger cows (D) and casein standards $(\mathrm{St})$.

In general, the milk from the Afrikaner, Bonsmara and Drakensberger contained more saturated fatty acids $(P<0.001)$ than that of the Boran, Nguni and Tuli, while the reverse was true of the monounsaturated fatty acids $(P<0.001)$. The highest levels of unsaturated fatty acids were observed for the Drakenberger $(78.4 \pm 2.32 \%)$ and the lowest for the Tuli $(60.9 \pm 4.72 \%)$. Responsible for the high concentration of saturated fatty acids in the milk from Afrikaner, Bonsmara and Drakensberger are mainly fatty acids, 4:0 - 14:0 $(P<0.001)$, while 18:1c9 $(P<0.001)$ and to a lesser extent 16:1c9 $(P<0.01)$ accounts for the low levels of mono-unsaturated fatty acids. Although the concentrations were very low, very long chain fatty acids and their unsaturated derivatives, 20 to 24 carbons in length, were detected mainly in the milk of the Boran, Nguni and Tuli. The 20:2(n-6) was present in all individuals at between $0.1 \%$ and $0.5 \%$ of these three breeds, while the longer fatty acids were present in the milk of only a few individual cows.

Detailed inspection of the content of some fatty acids showed that in the milk fat from Boran, Nguni and Tuli, the 4:0, 6:0, 8:0 and 12:0, at $P<0.001$ as well as $14: 0$ at $P<0.01$ of the Nguni and Tuli differed from that of the Afrikaner, Bonsmara and Drakensberger. The Tuli milk contained the lowest level of saturated fatty acids, specifically 4:0, 6:0, 8:0, 12:0, 14:0 and 16:0, while the Drakensberger contained the highest. In turn, Tuli milk contained the highest concentration of omega-3 fatty acids, and Drakensberger milk had the lowest. Tuli milk also contained the highest concentration of $17: 1 \mathrm{c} 10(P<0.001)$.

Closer inspection of the milk from the Afrikaner shows that some nutrients do not differ significantly from that of the Boran, and to a lesser extent the Nguni, expressly the concentration of whey, NPN, 8:0, 10:0, 12:0, 14:0, total saturated and total mono-unsaturated fatty acids. A similar 
inspection showed the same for the nutrients of Bonsmara milk, specifically the concentrations of 8:0, 14:0, total saturated and total mono-unsaturated fatty acids.

The data of Tables 1 and 2 were subjected to principal components analysis (PCA), the results of which are shown in Figure 2. Dimension 1 explains $64.4 \%$ of the variation, and dimension 2 explains $15.9 \%$. The data visually show that the milk composition of the Afrikaner and its derived beef breeds, Bonsmara and Drakensberger, forms a cluster recognized by its levels of fat, whey protein, NPN, saturated fatty acids, specifically of 4:0 to 16:0 lengths. The cluster of the Boran, Nguni and Tuli is recognized by its concentrations of lactose, mono-unsaturated fatty acids, specifically 14:1c9, 16:1c9, 17:1c10, 18:1c7 and 18:1c9. The PCA also shows that the milk composition of the Tuli differed from that of the Nguni and Boran, and that the milk composition of the Afrikaner was not so far removed from the other three indigenous breeds as that of the Bonsmara and Drakensberger, which are Afrikaner crossbred with European breeds.

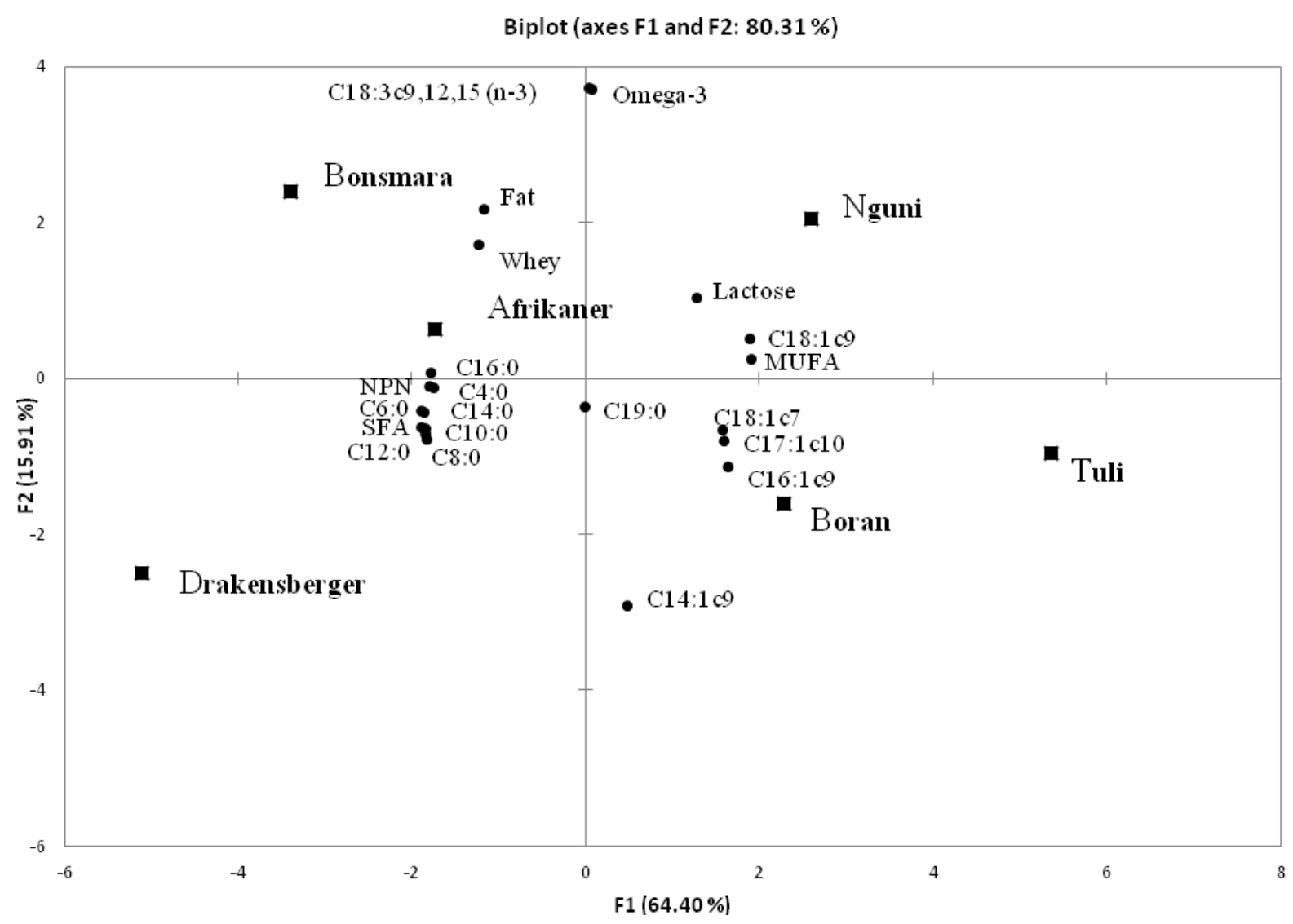

Figure 2 Principal component analysis of the milk composition of indigenous African cattle breeds, Boran, Nguni, Tuli, Afrikaner, Bonsmara and Drakensberger.

A comparison of the milk fatty acid concentration of the cattle under study with other members of the Bovinae sub-family shows that the milk fat from the Boran, Nguni and Tuli is comparable with that of the African buffalo (Osthoff et al., 2009b). The latter contains $58.7 \pm 5.01 \%$ saturated fatty acids, $31.3 \pm 3.56 \%$ mono-unsaturated fatty acids and $2.72 \pm 0.58 \%$ poly-unsaturated fatty acids, with the fatty acids of 4:0 to 14:0 in length, as well as the 18:1c9 being of the same order of magnitude. Small amounts of very long chain fatty acids were also found in the African buffalo milk, including 20:2(n-6), at approximately $1.1 \%$. The composition of the milk fatty acids from Afrikaner, Bonsmara and Drakensberger is more comparable with that reported from milk of dairy species. 
Similar results from Pakistan reported on the milk fatty acids of two breeds of sheep, the Kachi and Kooka, and two breeds of goat, the Kamori and Pateri, which were kept in the same environmental and feeding conditions (Talpur et al., 2009). One breed of each was shown to contain higher concentrations of saturated fatty acids, specifically of 4:0 to 16:0 lengths and lower concentrations of mono-unsaturated fatty acids, specifically 14:1c9, 16:1c9, 17:1c10, 18:1c7 and $18: 1 \mathrm{c} 9$, while the poly-unsaturated acids were similar in all breeds.

The highly significant $(P<0.001)$ difference in short to medium chain saturated fatty acids and the mono-unsaturated fatty acids, and also the presence of very long chain fatty acids, between the two cattle clusters, needs a separate discussion because it reflects on the synthesis of these acids. In ruminants, the concentration of $14: 0$ is above $10 \%$, normally around $14 \%$. In only a few species of the Bovidae family is its concentration above $16 \%$, such as the blackbuck antelope (Antilope cervicapra) (Dill et al., 1972) and the gazelle (Gazella granti) (Glass \& Jenness, 1971), while the highest concentrations have been recorded in the blesbok, $18.1 \%$, and the blue wildebeest at $20.6 \%$ (Osthoff et al., 2010). A high concentration of 14:0 is normally accompanied by a high content of the shorter saturated fatty acids, and these examples indicate a phylogenetic effect.

The genetic effect could be exerted on the supply system of dietary fatty acids via low density (LDL) and very low density (VLDL) lipoproteins (Glascock \& Welch, 1974), or on the enzymes in the fatty acid synthesis pathway, specifically the fatty acid synthase or the thioesterase that terminates the elongation process (Hawke \& Taylor, 1983; Neville et al., 1983). Since all the cattle in the current study were free roaming on the same vegetation type with no additional supplementary feed, the fatty acid uptake into, and release from lipoproteins can therefore be excluded as explanation.

The occurrence of very long chain fatty acids, especially 20:2(n-6), is also an indication that the fatty acid metabolism of the Boran, Nguni and Tuli differs from that of the Afrikaner, Bonsmara and Drakensberger. It is formed by elongation/desaturation of 18:0 by a $\Delta 12$ desaturase followed by an elongase (Guillou et al., 2010). While the roles of several of the enzymes involved in the elongation and desaturation steps in mammals have been identified with the use of transgenic mice (Guillou et al., 2010) the endoplasmic $\Delta 12$ desaturase has been found only in plants and lower eucaryotes (Fauconnot et al., 1999; Schwartzbeck et al., 2001). It is therefore unlikely that the synthesis of the $20: 2$ (n-6) is completed in the cow. It could originate from certain plants, which might indicate different dietary preferences between the cattle breeds. However, these breeds of cattle are not selective grazers (De Waal, 1990), so the effect of diet can be ruled out in this case. It could also indicate specialized bio-oxidation in the rumen, which would be an indication of unique symbiosis with specific rumen bacteria.

\section{Conclusion}

This investigation has shown that the nutrient composition of the milk, in particular the dry matter, of indigenous African cattle breeds that have not been bred for milk production is as low as that of European beef breeds. The content of whey proteins and NPN is also lower than that of other breeds. Great differences in milk fatty acid composition between the Sanga breeds and Afrikaner and its derivative breeds were observed, which would suggest the preference of certain fatty acid synthesis pathways. In future research the biochemical validation of this observation should be attempted.

\section{References}

Acocks, J.P.H., 1988. Veld types of South Africa. Memoirs of the Botanical Survey of South Africa, No. 57. Department of Agriculture and Water Supply, South Africa.

Atwal, A.S., Hidroglouant, M., Kramer, J.K.G. \& Binns, M.R., 1990. Effects of feeding $\alpha$-tocopherol and calcium salts of fatty acids on vitamin E and fatty acid composition of cow's milk. J. Dairy Sci. 73, 2832-2841.

Bonsma, F.N., Bisschop, J.H.R., Curson, H.H., Van Rensburg, P., Van Rensburg, J.A., Van Wyk, H.P.P., Barnard, W.G. \& Watermeyer, F., 1951. Nguni cattle: Report on indigenous cattle in South Africa. Pamphlet no. 311 of the Department of Agriculture of the Union of South Africa. 
Bonsma, J.C., 1980. Cross-breeding, breed creation and the genesis of the Bonsmara. In: Livestock Production. A Global Approach. Ed. Bonsma, J.C., Tafelberg Publishers Ltd., Cape Town.

Chilliard, Y., Ferlay, A. \& Doreau, M., 2001. Effect of different types of forages, animal fat or marine oils in cow's diet on milk fat secretion and composition, especially conjugated linoleic acid (CLA) and polyunsaturated fatty acids. Livest. Prod. Sci. 70, 31-48.

Chilliard, Y., Glasser, F., Ferlay, A., Bernard, L., Rouel, J. \& Doreau, M., 2007. Diet, rumen biohydrogenation and nutritional quality of cow and goat milk fat. Eur. J. Lipid Sci. Technol. $109,828-855$.

Csapó, J., Martin, T.G., Csapó-Kiss, Z.S. \& Hazas, Z., 1996. Protein, fats, vitamin and mineral concentrations in porcine colostrums and milk from partition to 60 days. Int. Dairy J. 6, 881-902.

De Passillé, A.M.B. \& Rushen, J., 1999. Are you a source of stress or comfort for your cows? Adv. Dairy Technol. 11, 347-360.

De Waal, H.O., 1990. Animal production from native pasture (veld) in the Free State Region - a perspective of the grazing ruminant. S. Afr. J. Anim. Sci. 20, 1-9.

De Waal, H.O., Osthoff, G., Hugo, A., Myburgh, J. \& Botes, P., 2004. The composition of African lion (Panthera leo) milk collected a few days postpartum. Mamm. Biol. 69, 1-9.

Dils, R.R., Clark S. \& Knudsen, J., 1977. Comparative aspects of milk fat synthesis. Symp. Zool. Soc. Lond. 41, 43-55.

Fauconnot, L., Nugier-Chauvin, C., Noiret, N., Poulain, S. \& Patin, H., 1999. Regio- and enantioselective oxidation of thiaoleic acids by an algal D12-desaturase. Phytochem. 52, 567-573

French, P., Stanton, C., Lawless, F., O 'Riordan, E.G., Monahan, F.J., Caffrey, P.J. \& Moloney, A.P., 2000. Fatty acid composition, including conjugated linoleic acid, of intramuscular fat from steers offered grazed grass, grass silage or concentrate-based diets. J. Anim. Sci. 78, 2849-2855.

Folch, J., Lees, M. \& Sloane-Stanley, G.H., 1957. A simple method for the isolation and purification of total lipids from animal tissue. J. Biol. Chem. 226, 497-509.

Glascock, R.F. \& Welch, V.A., 1974. Contribution of the fatty acids of three low density serum lipoproteins to bovine milk fat. J. Dairy Sci. 57, 1364-1370.

Glass, R.L. \& Jenness, R., 1971. Comparative biochemical studies of milk - VI. Constituent fatty acids of milk fats of additional species. Comp. Biochem. Physiol. B 38, 353-359.

Guillou, H., Zadravec, D., Martin, P.G.P. \& Jacobsson, A., 2010. The key roles of elongases and desaturases in mammalian fatty acid metabolism: Insights from transgenic mice. Prog. Lipid Res. 49, 186-199.

Haenlein, G.F.W. \& Wendorff, W.L., 2006. Sheep milk. In: Handbook of Milk of Non-bovine Mammals. Eds Park, Y.W. \& Haenlein, G.F.W., Blackwell, London. pp. 137-194.

Hood, R.H., Kunz, T.H., Oftedal, O.T., Iverson, S.J., Le Blanc, D. \& Seyagat, J., 2001. Interspecific and intraspecific variation in proximate, mineral and fatty acid composition of milk in old world fruit bats (Chiroptera: Pteropodidae). Physiol. Biochem. Zool. 74, 134-146.

Igarashi, Y., 1995. An improved procedure for the preliminary fractionation of milk proteins. Int. Dairy J. 5, 305-310.

Iverson, S.J. \& Oftedal, O.T., 1995. Phylogenetic and ecological variation in the fatty acid composition of milks. In: Handbook of Milk Composition. Ed Jensen, R.G., Academic Press, New York. pp. 790-827.

Jacobsen, K.L., De Peters, E.J., Rogers, Q.R. \& Taylor, S.J., 2004. Influences of stage of lactation, teat position and sequential milk sampling on the composition of domestic cat milk (Felis catus). J. Anim. Physiol. Anim. Nutr. 88, 46-58.

Jenkins, T.C., 1993. Lipid metabolism in the rumen. J. Dairy Sci. 76, 3851-3863.

Jenkins, T.C. \& Bridges, W.C., 2007. Protection of fatty acids against ruminal biohydrogenation in cattle. Eur. J. Lipid Sci. Technol. 109, 778-789. 
Jenkins, T.G. \& Ferrell, C.L., 1984. A note on lactation curves of crossbred cows. Anim. Prod. 39: 479-482.

Jenness, R. \& Patton, S., 1976. Principles of Dairy Chemistry. Wiley \& Sons, London.

Jensen, R.G., 1995. Handbook of Milk Composition. Academic Press, London.

Kadzere, C.T., Murphya, M.R., Silanikoveb, N. \& Maltz, E., 2002. Heat stress in lactating dairy cows: a review. Livest. Prod. Sci. 77, 59-91.

Kothapalli, K.S.D., Anthony, J.C., Pan, B.S., Hsieh, A.T., Nathanielsz, P.W. \& Brenna, J.T., 2007. Differential cerebral cortex transcriptones of baboon neonates consuming moderate and high docosahexaenoic acid formulas. PLoS ONE (4), e370.

Litwinczuk, Z. \& Krol, J., 2002. The yield and composition of beef cow's milk and the results of calf rearing. Animal Science Papers and Reports 20, Suppl. 1, 199-204. Institute of Genetics and Animal Breeding, Jastrizebiec, Poland.

Lkhagvajav, B., 1978. Lipido-acidic composition of milk fat of Mongolian yak and khaihags. J. Food. Technol. 4, 41-43.

Makrides, M., Neumann, M.A., Byard, R.W., Simmer, K. \& Gibson, R.A., 1994. Fatty acid composition of brain, retina and erythrocytes in breast fed and formula fed infants. Am. J. Clin. Nutr. 60, 189-194.

Meyer, E.H.H., 1984. Chromosomal and biochemical genetic markers of cattle breeds in Southern Africa. In: Proceedings of the 2nd World Congress on Sheep and Beef Cattle Breeding, Pretoria, South Africa.

Milligan, L.A. \& Bazinet, R.P., 2008. Evolutionary modifications of human milk composition: evidence from long-chain polyunsaturated fatty acid composition of anthropoid milks. J. Human Evolution 55, 1086-1095.

Mills, D.E., Ward, R.P. \& Huang, Y.S., 1990. Fatty acid composition of milk from genetically normotensive rats. J. Nutr. 120, 431-435.

Myher, J.J., Kuksis, A., Tilden, C. \& Oftedal, O.T., 1994. A cross-species comparison of neutral lipid composition of milk fat of prosimian primates. Lipids 29, 411-419.

NCSS, 2007. Statistical System for Windows. NCSS Statistical Systems, Kaysville, Utah, USA.

Neville, M.C., Allen, J.C. \& Watters, C., 1983. Mechanisms of milk secretion. In: Lactation; Physiology, Nutrition and Breast-feeding. Eds Neville, M.C. \& Neifert, M.R., Plenum Press New York.

Offer, N.W., Marsden, M., Dixon, J., Speake, B.K. \& Thacker, F.E., 1999. Effect of dietary fat supplements on levels of $\mathrm{n} 3$ polyunsaturated fatty acids, trans acids and conjugated linoleic acid in bovine milk. Anim. Sci. 69, 613-625.

Oftedal, O.T., 1984. Milk composition, milk yield and energy output at peak lactation: a comparative review. Symp. Zool. Soc. Lond. 51, 33-85.

Osthoff, G., Hugo, A., De Waal, H.O. \& Botes, P., 2005. The composition of African elephant (Loxodonta africana) milk collected a few days postpartum. Comp. Biochem. Physiol. 141, 223-229.

Osthoff, G., Hugo, A., De Wit, M., Nguyen, T.P.M. \& Seier, J., 2009a. Milk composition of captive vervet monkey (Chlorocebus pygerythrus) and rhesus macaque (Macaca mulatta) with observations on gorilla (Gorilla gorilla gorilla) and white handed gibbon (Hylobates lar). Comp. Biochem. Physiol. B 152, 332-338.

Osthoff, G., Hugo, A., De Wit, M. \& Nguyen, T.P.M., 2009b. The chemical composition of milk from free-ranging African buffalo (Syncerus caffer). S. Afr. J. Wildl. Res. 39, 97-102.

Osthoff, G., Hugo, A. \& De Wit, M., 2009c. Comparison of the milk composition of free-ranging blesbok, black wildebeest and blue wildebeest of the subfamily Alcelaphinae (family: Bovidae). Comp. Biochem. Physiol. B 154, 48-54.

Payne, W.J.A., 1970. Cattle production in the tropics. Vol. 1. General Introduction and Breeds and Breeding. Longman, London.

Pandya, A.J. \& Khan, M.M., 2006. Buffalo milk utilization for dairy products. In: Handbook of Milk of Non-bovine Mammals. Eds Park, Y.W. \& Haenlein, G.F.W., Blackwell, London. 
Park, P.W. \& Goins, R.E., 1994. In situ preparation of fatty acid methyl esters for analysis of fatty acid composition in foods. J. Food. Sci. 59, 1262-1266.

Park, Y.W., 2006. Goat milk - chemistry and nutrition. In: Handbook of Milk of Non-bovine Mammals. Eds Park, Y.W. \& Haenlein, G.F.W., Blackwell, London.

Power, M.L., Oftedal, O.T. \& Tardif, S.D., 2002. Does the milk of Callitrichid monkeys differ from that of larger anthropoids? Am. J. Primatol. 56, 117-127.

Purcell, R.H., Sun, B., Pass, L.L., Power, M.L., Moran, T.H. \& Tamashiro, K.L.K., 2011. Maternal stress and high-fat diet effect on maternal behavior, milk composition, and pup ingestive behaviour. Physiol. Behavior 104, 474-479.

Schwartzbeck, J.L., Jung, S., Abbott, A.G., Mosley, E., Lewis, S., Pries, G.L. \& Powel, G.L., 2001. Endoplasmic oleoyl-PC desaturase references the second double bond. Phytochem. 57, 643-652.

Strydom, P.E., 2008. Do indigenous Southern African cattle breeds have the right genetics for commercial production of quality meat? Meat Sci. 80, 86-93.

Talpur, F.N., Bhanger, M.I. \& Memon, N.N., 2009. Milk fatty acid composition of indigenous goat and ewe breeds from Sindh, Pakistan. J. Food Comp. Anal. 22, 59-64.

Tilden, C.D. \& Oftedal, O.T., 1997. Milk composition reflects pattern of maternal care in prosimian primates. Am. J. Primatol. 41, 195-211. 